\title{
外側型腰椎椎間板ヘルニア手術例の検討
}

\begin{tabular}{|c|c|c|c|c|c|}
\hline \multicolumn{6}{|c|}{ ヘートライフ病院整形外科 } \\
\hline 黒 島 & & 聡・松 & 元 & & 悟 \\
\hline 佐久本 & 嗣 & 夫・六 & 角 & 高 & \\
\hline 求大学整形外科 & & & & & \\
\hline 屋 良 & 哲 & 也・新 & 垣 & 勝 & \\
\hline 金 谷 & 文 & 則 & & & \\
\hline
\end{tabular}

\section{Surgical Results of Lateral Lumbar Disc Herniation}

\author{
Satoshi Kuroshima, Satoru Matsumoto, Tsuguo Sakumoto, \\ and Takayoshi Rokkaku \\ Orthopaedic Surgery, Heart Life Hospital, Nakagusuku, Okinawa, Japan \\ Tetsuya Yara, Katsuo Arakaki, and Fuminori Kanaya \\ Department of Orthopedic Surgery, School of Medicine, University of \\ the Ryukyus, Nishihara, Okinawa, Japan
}

\begin{abstract}
We experienced 134 cases of surgically treated lumbar disc herniation within the past seven years. Six of these cases, all males, showed lateral lumbar disc herniation. We studied these cases with regard to involved levels in the sagittal plane and localization in the horizontal plane, surgical procedure and postoperative improvement. The average age at the time of surgery was 44.2 years old, with a range between 27 and 62 years. The average follow-up period was 2 years with a range from 8 months to 3 years and 8 months. The level was L3/4 in one case, L4/5 in two cases, L5/S in three cases. Localization of herniation in the horizontal plane was extraforaminal in five cases, and intraforaminal herniation associated with L5 spondylolysis was seen in one case. In the former five cases, we performed resection of herniated discs following lateral fenestration, and in the other case herniated disc was removed after Gill's method, followed by posterolateral fixation Clinical symptoms improved in all cases after surgery. The mean Japanese Orthopaedic Association (JOA) scores of lumbar spine before surgery were 13 out of 29 points and after surgery were 26 points.

The mean improvement rate was 60 percent.
\end{abstract}

Key words : lateral lumbar disc herniation (外側型腰椎椎間板ヘルニア), lateral fenestration (外側 開空), Gill's procedure (Gill 法)

\section{はじめに}

外側型腰椎椎間板へルニアは画像では捉えがたいへ ルニアとして知られてきたが, MRI，CT-discography（以下 CTD）などの各種画像検査の発達で診断
は比較的容易になってきた，通常の脊柱管内ヘルニア と比べて下肢痛が強いのが特徴的で, 治療法について は様々な手術法の報告があり，まだ統一された術式は ない，我々は外側型腰椎椎間板へルニア 6 例に手術を 行い，良好な結果を得たので報告する。 


\begin{tabular}{ccccc}
\multicolumn{2}{c}{ 表 1 } & ヘルニアの発生高位, 局在および術式 \\
\hline \hline 症例 & 年齢 & 高位 & 局 在 & \multicolumn{1}{c}{ 術 式 } \\
\hline 1 & 47 & L3 $/ 4$ & 椎間孔外 & 外側開空法 \\
\hline 2 & 50 & L4/5 & 椎間孔外 & 外側開悹法 \\
\hline 3 & 43 & L4/5 & 椎間孔外 & 外側開悹法 \\
\hline 4 & 62 & L5/S & 椎間孔外 & 外側開空法 \\
\hline 5 & 27 & L5/S & 椎間孔外 & 外側開空法 \\
\hline 6 & 36 & L5/S & 椎間孔内 & Gill 法 \\
& & & & 後側方固定 \\
\hline
\end{tabular}

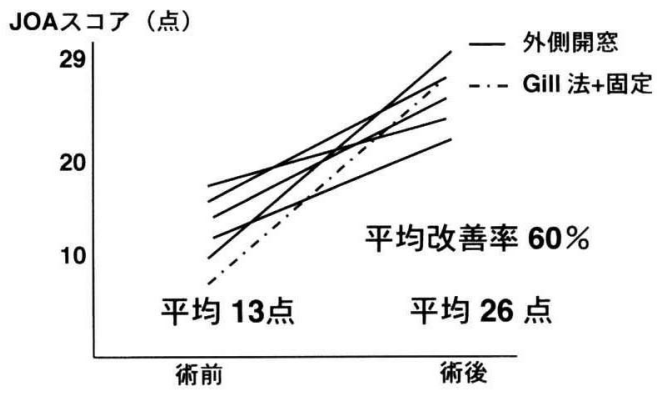

図 1 術前後JOA score の推移

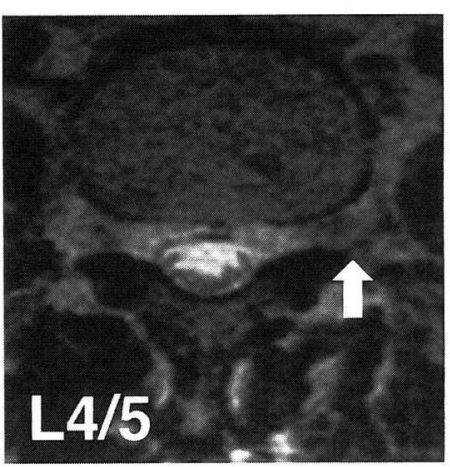

a

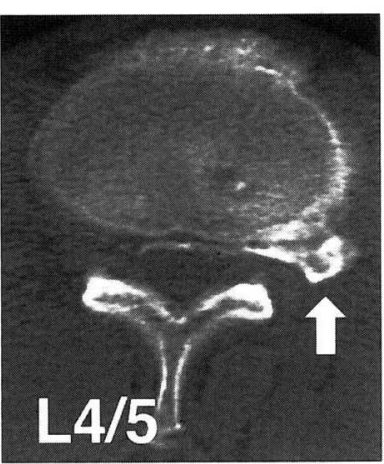

b

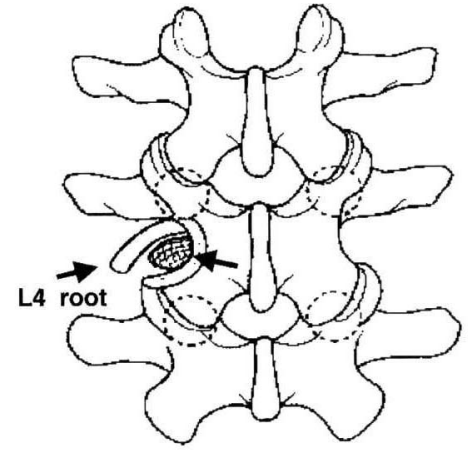

c

図 2 症例 1
a. 術前 MRI (T 2 W)
b. 術前 CT-discography
c. 外側開空術

対

象

対象は平成 6 年 7 月より平成 12 年 3 月までに経験 した外側型腰椎椎間板へルニア手術例の 6 例（全例男 性）で，年齢は 27〜62 歳（平均 44.2 歳）であった。 ヘルニアの発生高位は L3/4: 1 例, L4/5: 2 例, L5/ $\mathrm{S}: 3$ 例で, 横断位局在は椎間孔外 5 例, 椎間孔内 1 例であった，椎間孔外の 1 例は L $5 / \mathrm{S} レ$ ベルであり L5 分離を合併していた。手術は椎間孔外ヘルニア例 に対しては外側開空法にてへルニアを摘出し, 椎間孔 内ヘルニアに分離を合併した 1 例は分離椎弓を切除 （Gill 法）しヘルニアを摘出した後, ペディクルスク リューを用いた外側方固定術を行った（表 1 ）. 経過 観察期間は 8 力月〜 3 年 8 力月（平均 2 年）であった.
結果

術後全例で臨床症状の改善を認め日整会腰痛疾患治 療成績判定基準（JOA） スコア術前平均 13 点が術後 26 点に改善し, 平均改善率は $60 \%$ であった（四 1 ). 外側開空法の 5 例は椎体すべりも椎間不安定性む生じ ず，固定を行った分離合併の 1 例も骨癒合が得られた.

症例

【症例 1 】 43 歳, 男性 主訴：左下肢前面痛, しびれ

現病歴：平成 10 年 1 月 7 日より主訴が出現し外来受 診。仙骨ブロックを行うも改善を認めず増悪したため 1 月 12 日に入院となった。

入院時理学所見：下肢伸展挙上テストは左 $30^{\circ}$ で陽性 


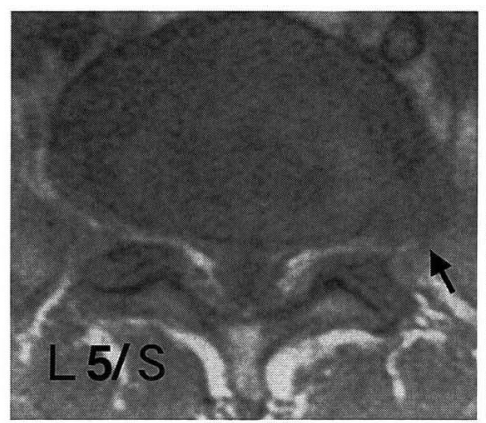

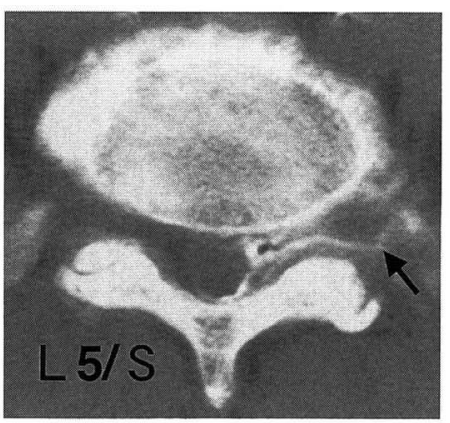

b

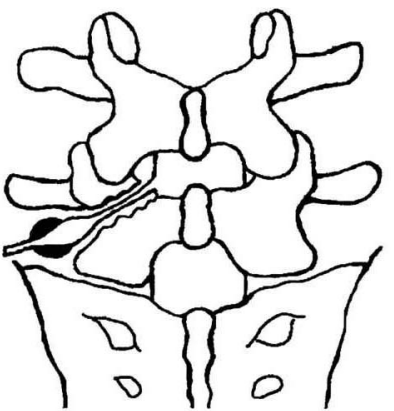

c

図 3 症例 2
a. 術前 MRI（T1W）
b. 術前 CT-discography
c. 手術法

であり下肢筋力は左大腿四頭筋が MMT 3 -, 左八ム ストリングが 3 と低下し, 下肢腱反射は正常であった。 画像所見：MRI では L4/5レベルの横断像で左側椎 間孔外にヘルニアを認めた。また，CTDにて同レベ ルで造影剂の漏出を認めた（図 $2 \mathrm{a}, \mathrm{b}$ ).

入院後経過：持続硬膜外ブロックを 9 日間施行し安静 時の疼痛は消失したが体動時の左下肢疼痛は持続し歩 行が困難であったため, 全麻下に外側開空法（図 2 c）にて脱出ヘルニアの摘出を行った. 術後疼痛は 軽減し, JOA スコア術前 6 点が術後 27 点に改善した.

【症例 $2 】 62$ 歳, 男性

主訴：左下腿痛, しびれ

現病歴：平成 5 年 11 月より主訴が出現したため近医 受診し，理学療法を受けたが改善しなかったため，平 成 6 年 4 月 14 日当院受診し入院となった.

入院時理学所見：下肢伸展挙上テストは左 $60^{\circ}$ で陽性 であり下肢筋力は左前脛骨筋が 5 -, 左長母趾伸筋が $3+$ と低下し，下肢腱反射は正常であった．

画像所見：MRI では L5/Sレベルの横断像で左側椎 間孔外にヘルニアを認めた。 また，CTDにて同レべ ルで造影剤の漏出を認めた（図 $3 \mathrm{a}, \mathrm{b}$ ).

入院後経過：平成 6 年 5 月 2 日全麻下に外側開空法に てアプローチしたが L5 rootの同定が困難であったた め近位より L5 root, ヘルニアを同定した後にヘルニ アを摘出した（図 $3 \mathrm{c}$ ). 術後疼痛は軽減し, JOA ス コア術前 19 点が術後 25 点に改善した。

【症例 3 】 36 歳, 男性
主訴：腰痛, 左下肢痛, しびれ

現病歴：平成 9 年 6 月より主訴が出現したため近医に て理学療法, 仙骨ブロックを受けたが改善しなかった ため平成 9 年 10 月 22 日当院初診. 手術的加療目的に て平成 9 年 12 月 1 日入院となった.

入院時理学所見: 下肢伸展挙上テスト, 大腿神経伸展 テストはともに両側とも陰性であり，下肢筋力，下肢 腱反射は正常であった。

画像所見：X線像で L5 分離を認め, MRI では L5/S レベルの横断像で左側椎間孔外にヘルニアを認めた (威 4 a, b).

臨床経過：12月 3 日全麻下に Gill 法でアプローチし 椎間孔内のへルニアを摘出後, 後側方固定を行った (図 4 c, d). JOA スコア術前 16 点が術後 27 点に 改善した。

\section{考察}

外側型腰椎椎間板へルニアの発生頻度は全へルニア 中 $\left.7.5 \sim 8.2 \%^{1)^{4}}\right)^{9)}$ とされている. 平成 6 年から平成 12 年に扝ける当院での発生率はヘルニア手術症例 134 例中 6 例， $4.5 \%$ であった。春柱管内ヘルニアとの臨 床像の相違については, 後根神経節 (以下 DGR) の 圧迫により下肢痛, しびれが強い傾向が報告されてい

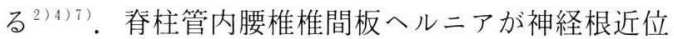
部での圧迫病变であるのに対して, 外側型腰椎椎間板 ヘルニアでは椎間孔内执び孔外にわたり存在する DRG がヘルニア塊により直接圧迫・刺激される. 実 


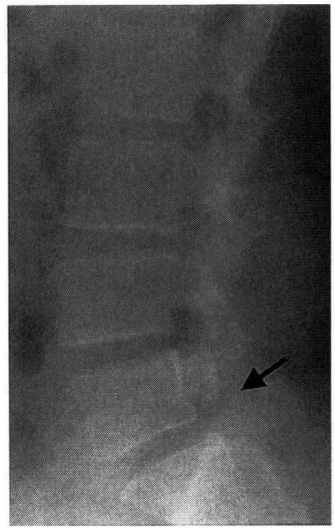

a

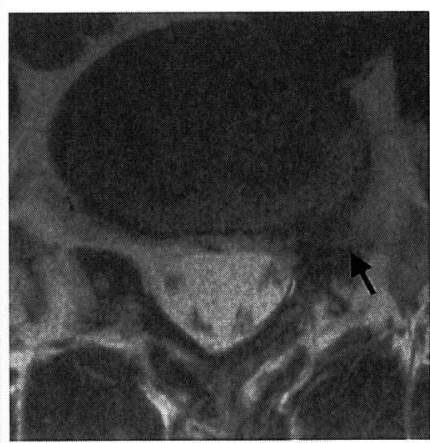

b

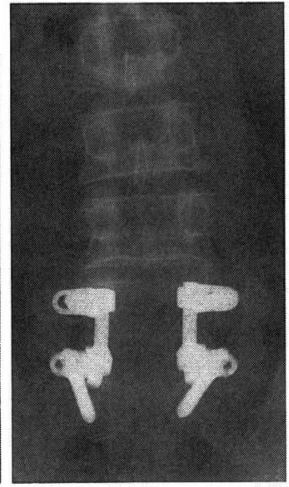

C

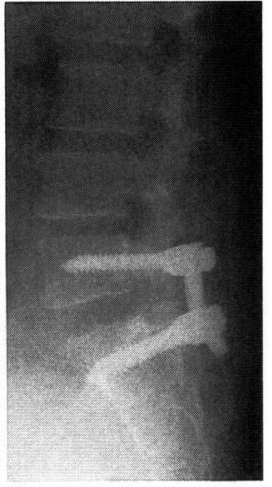

d

図 4 症例 3
a. 術前 X線像
b. 術前 MRI (T2W)
$c, d$. 術後 X線像

験的には DRG は神経根よりむ機械的刺激に対する感 受性が高く, DRG に対する機械的圧迫は一次性知覚 ニューロンの異常活動を惹起し, 激しい下肢痛を引き 起こすとの報告がある2?.

治療法について過去の報告は手術療法によるものが ほとんどで，保存的療法に関する報告は少ないが，外 側型と通常型の手術率に差は認められず，外側型でも 約半数はステロイドの椎間板内注入療法や選択的神経 根ブロックによって治療できたとの報告もある ${ }^{4}$. 私 たちの症例も同様の臨床像を示したが，保存的療法に は抵抗性で手術を要した。手術法については外側開空 法 ${ }^{6)} 8$ ) 100111 , 片側椎間関節切除術打よび後側方固定術の 併用 ${ }^{(1) 6)}$, 骨形成的片側椎弓切除術3)5 などが報告さ れている. 術式の選択にあたってはへルニアが椎間孔 内および孔外にわたり存在するか, 椎間孔外に偏在す るかを MRI や CTD で局在診断をする必要がある。 ヘルニアが椎間孔内および孔外にある場合は, 片側椎 間関節切除により直視下にヘルニアを摘出できるが. 後側方固定術を要するという欠点がある(1)3/5)6). ヘル ニアが椎間孔外に偏在する場合は椎間関節を温存し固 定術を併用しない外側開空法で摘出可能であるが視野 が狭い欠点がある ${ }^{1 / 6)}$. 両者の欠点を克服する術式之 して骨形成的片側椎弓切除術屯行われている ${ }^{3 / 5}$. 我々 の症例のうち 5 例は椎間孔外に偏在したため最小侵襲 の外側開空法でへルニアを摘出できたが，椎間孔内・
分離例 1 例に対してはGill 法後にへルニアを摘出し, 後側方固定術を行い良好な結果を得た。

\section{ま と め}

1. 外側型腰椎椎間板ヘルニア手術例の 6 例を報告し た。

2. 術式は椎間孔外ヘルニア 5 例に外側開空術を行い, 椎間孔内ヘルニア・分離合併 1 例に対し Gill 法と 後側方固定術老行った。

3. 術後全例が改善し平均改善率は $60 \%$ であった。

\section{参 考 文 献}

1）鎧 邦芳ほか：Extraforaminal lateral lumbar disc herniation の診断之治療. 日整会誌, 61 : S920, 1987.

2）生田 光, 大賀正義：椎間孔内 - 外腰椎椎間板ヘルニ アの臨床症状. 日脊外誌, $11 ： 287.2000$.

3）小田裕胤はか：Extraforaminal lumbar disc herniation に対する骨形成的椎弓切除術の有用性. 日整会誌, 6 : S632, 1992.

4）加藤文彦, 吉原永武, 筑瀬 誠: 外側型腰椎椎間板へ ルニアの治療成績. 日脊外誌. $11: 288,2000$.

5）白石 元ほか：Extraforaminal lumbar disc herniation (ELDH) に対する骨形成的偏側椎弓切除術. 整形外 科之災害外科, $45 ： 736-738,1996$.

6）千葉光穂ほか：外側型腰椎椎間板へル二アの術式の検 討. 日脊外誌, $11 ： 289,2000$.

7）永島英樹ほか：腰椎椎間板外側ヘル二アの臨床像. 日 脊外誌, $11: 286,2000$. 
8）猫塚義夫ほか：腰椎椎間孔内・外神経根絞扼における 手術治療例の臨床的検討. 日脊外誌, $7: 35,1996$.

9）藤谷正紀ほか：Extraforaminal lateral lumbar disc herniation. 臨整外, $21: 3-11,1986$.

10）森山明夫ほか：Extreme lateral lumbar disc hernia- tion に対しての外側開空法による䯣核摘出術の試み。整 形外科, $41: 1047-1052,1990$.

11）森山明夫ほか：腰部外側神経根障害に対する外側開空 術の中期成績. 臨整外, 32:507-514, 1997. 